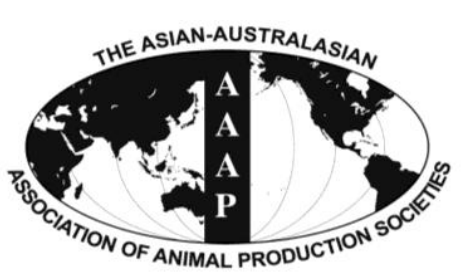

Open Access

Asian Australas. J. Anim. Sci.

Vol. 28, No. 2 : 247-251 February 2015

http://dx.doi.org/10.5713/ajas.14.0492

www.ajas.info

pISSN 1011-2367 elSSN 1976-5517

\title{
Effects of Onion Extracts on Growth Performance, Carcass Characteristics and Blood Profiles of White Mini Broilers
}

\author{
B. K. An, J. Y. Kim, S. T. Oh, C. W. Kang ${ }^{1}$, S. Cho, and S. K. Kim* \\ Department of Animal Science and Technology, Konkuk University, Seoul 143-701, Korea
}

\begin{abstract}
This experiment was carried out to investigate effects of onion extract on growth performance, meat quality and blood profiles of White mini broilers. Total of 600 one-d-old male White mini broiler chicks were divided into four groups and fed control diets (non-medicated commercial diet or antibiotics medicated) or experimental diets (non-medicated diets containing $0.3 \%$ or $0.5 \%$ onion extract) for 5 wks. The final body weight (BW) and weight gain of the group fed non-medicated control diet were lower than those of medicated control group ( $\mathrm{p}<0.01$ ). The chicks fed diet with $0.3 \%$ or $0.5 \%$ onion extract showed a similar BW to that of medicated control group. The relative weight of various organs, such as liver, spleen, bursa of Fabricius, abdominal fat, and the activities of serum enzymes were not affected by dietary treatments. There were no significant differences in meat color among groups. Whereas, groups fed diets containing onion extract had slightly lower cooking loss and higher shear force value, but not significantly. The concentrations of serum free cholesterol and triacylglycerol in groups fed diet containing onion extract were significantly decreased compared with those of controls $(\mathrm{p}<0.01)$. In conclusion, the onion extracts exerted a growth-promoting effect when added in White mini broiler diets, reflecting potential alternative substances to replace antibiotics. (Key Words: Onion Extract, Growth Performance, Serum Cholesterol, Blood Profiles, White Mini Broilers)
\end{abstract}

\section{INTRODUCTION}

The sub-therapeutic uses of antibiotics to enhance growth and prevent the infectious intestinal diseases have led to a problem of drug residues in final animal products and emerge of new antibiotic-resistance bacteria (Frankic et al., 2009). In Korea, the routine use of antibiotics in poultry diets have been banned and thus, some endeavors are made to develop new in-feed antibiotics substitutes for reducing and treating infectious diseases in poultry industry. The herb and botanicals are increasingly being used in animal feeds, in place of antibiotics, as possible alternative means to prevent infectious diseases and modulate the immune responses (Wenk, 2003).

Onion (Alliium cepa L.) which belongs to the family Liliaceae is extensively used as food and the common medicinal plants. Onion bulbs have numerous organic

\footnotetext{
* Corresponding Author: S. K. Kim. Tel: +82-2-450-3728,

E-mail: sookikim@konkuk.ac.kr

${ }^{1}$ Dan Biotech Inc., Cheonan 330-834, Korea.

Submitted Jun. 30, 2014; Revised Oct. 14, 2014; Accepted Nov. 8, 2014
}

sulphur compounds, flavonoids and phenolic acids with proven antibacterial, antioxidant and hypolipidemic efficacy (Melvin Joe et al., 2009; Srinivasan et al., 2004). The serum cholesterol was significantly decreased by dietary dehydrated onion in experimentally hypercholesterolemic rats (Vidyavati et al., 2010). Goodarzi et al. (2013) reported that the beneficial influence of onion extract on the growth performance in meat-type broiler chickens.

The White mini broiler (WMB) is a local mixed breed produced by crossbreeding between meat-type male breeder and egg-type hens. The meat from WMB has unique texture with not too tender and is mainly used as raw meat for retort products, called Samgyetang. The production of WMB has been continuously increased, still having a small market, because consumer's preference for Samgyetang is growing in this region. The WMB show relatively slowgrowth with poor feed efficiency than fast-growing broilers. They were capable of a feed efficiency of $50 \mathrm{~g}$ of body weight (BW) gain per $100 \mathrm{~g}$ feed consumption with about $900 \mathrm{~g} \mathrm{BW}$ at 31-d old (Choo at al., 2014). For maximal growth and optimal feed conversion ratio, the commercial

Copyright (? 2015 by Asian-Australasian Journal of Animal Sciences This is an open-access article distributed under the terms of the Creative Commons Attribution Non-Commercial License (http://creativecommons.org/licenses/by-nc/3.0/), which permits unrestricted non-commercial use, distribution, and reproduction in any medium, provided the original work is properly cited. 
broiler diets with antibiotic-based growth promoters has been fed to WMB until the use of antibiotics was prohibited. The objectives of this study were to determine the dietary effects of onion extracts as in-feed antibiotics substitutions on growth performance, carcass characteristics and blood lipid profiles of WMB.

\section{MATERIALS AND METHODS}

\section{Diets, animals and management}

Fresh onion bulbs (Alliium cepa L.) were purchased from local market (Emart Inc., Seoul, Korea). They were peeled and grated by mixer (HR 2160, Artreal Manufacturing Ltd., Huiyang, China) without water addition. Leuconnostoc citreum SK1984 was inoculated at final level of $1 \%$ into onion juice containing medium and incubated at $30^{\circ} \mathrm{C}$ for $24 \mathrm{~h}$. The molasses of $6.5 \mathrm{~g} / \mathrm{L}$ and yeast extract of $10.0 \mathrm{~g} / \mathrm{L}$ were provided as media ingredients as previously suggested (Chang et al., 2010). The obtained onion extract was sprayed and well mixed with non-medicated control diet.

On the day of hatch, White mini broiler chicks were received from a local hatchery (Fineth hatchery Co. Ltd., Chungju, Korea). They were weighed individually and randomly assigned into four experimental treatments with five replicates of 30 chicks. A total of 600 chicks were housed on rice husks in floor pens with 23/1 light/dark cycle throughout the experimental period and fed one of four diets (antibiotic medicated, non-medicated diets, nonmedicated diets with $0.3 \%$ or $0.5 \%$ onion extract) for $35 \mathrm{~d}$ of rearing period. The non-medicated diet were purchased from a commercial feed manufacture (Seoulfeed Co. Ltd., Inchon, Korea) (Table 1), and mixed with avilamycin (10 ppm) or different doses of onion extract. The chicks were allowed to have free access to diet and water. The chicks were initially reared at $33^{\circ} \mathrm{C}$; the room temperature was gradually decreased by $4^{\circ} \mathrm{C}$ weekly until a final temperature of $23^{\circ} \mathrm{C}$ was reached. The experimental diets were freshly added everyday and feed intake of each replicate was recorded weekly. The BW on a pen basis was recorded weekly and feed efficiency was also calculated. All animal care procedures were approved by Institutional Animal Care and Use Committee in Konkuk University.

\section{Sample preparations and measurements}

At the end of the experimental period, 10 chicks per each treatment were selected and weighed individually. The blood was taken from jugular veins and analyzed for the activities of glutamic-oxaloacetic transaminase (GOT) and glutamic-pyruvic transaminase (GPT). The activities of GOT and GPT in serum were measured according to the colorimetric method as previous described (An et al., 2007).

The liver, spleen, bursa of Fabricius, abdominal fat,
Table 1. Formula and chemical compositions of the experimental diet

\begin{tabular}{lc}
\hline Items & \\
\hline Ingredients, \% & 47.29 \\
Yellow corn & 8.00 \\
Wheat & 31.60 \\
Soybean meal & 3.87 \\
Corn gluten meal & 5.5 \\
Tallow & 0.20 \\
Vit. and Min. mixture ${ }^{1}$ & 0.11 \\
DL-methionine (98.5\%) & 1.90 \\
Dicalcium phophate & 1.13 \\
Limestone & 0.08 \\
Choline-Cl (50\%) & 0.32 \\
Salt & 100.00 \\
Total & \\
Calculated composition & 3,150 \\
TMEn (kcal/kg) & 21.50 \\
CP (\%) & 1.00 \\
Ca (\%) & 0.45 \\
Available P (\%) & 1.10 \\
Lysine (\%) & 0.85 \\
Methionine+cystine (\%)
\end{tabular}

TMEn, nitrogen-corrected true metabolizable energy; $\mathrm{CP}$, crude protein.

${ }^{1}$ Vit. and Min. mixture provided the following nutrients per $\mathrm{kg}$ of diet: vitamin $\mathrm{A}, 40,000 \mathrm{IU}$; vitamin $\mathrm{D}_{3}, 8,000 \mathrm{IU}$; vitamin $\mathrm{E}, 10 \mathrm{IU}$; vitamin $\mathrm{K}_{3}, 4.0 \mathrm{mg}$; vitamin $\mathrm{B}_{1}, 4.0 \mathrm{mg}$; vitamin $\mathrm{B}_{2}, 12.0 \mathrm{mg}$; vitamin $\mathrm{B}_{6}, 6.0 \mathrm{mg}$; vitamin $\mathrm{B}_{12}, 0.02 \mathrm{mg}$; niacin, $60.0 \mathrm{mg}$; pantothenic acid, $20 \mathrm{mg}$; folic acid, $2.0 \mathrm{mg}$; biotin, $0.02 \mathrm{mg}$; Fe, $30.0 \mathrm{mg}$; Zn, $25.0 \mathrm{mg}$; Mn, $20.0 \mathrm{mg}$; $\mathrm{Cu}, 5.0 \mathrm{mg} ; \mathrm{Se}, 0.1 \mathrm{mg}$.

breast and leg were immediately removed and weighed. The data were expressed as grams of organ per $100 \mathrm{~g} \mathrm{BW}$. The chicks selected were sacrificed by neck cut, scalded with hot water $\left(55^{\circ} \mathrm{C}\right.$ for $\left.2 \mathrm{~min}\right)$, and removed the feathers mechanically. Carcasses were eviscerated manually and portioned into commercial cuts such as neck, breast, leg and wing. The breasts were immediately chilled for $30 \mathrm{~min}$ in ice water and transferred to icebox and then prepared separately for further analyses.

The contents of each lipid fraction in the liver and serum were separated by thin layer chromatography (TLC) on silica gel chromarods (Chromarod-S III, Mitshbishi Kagaku Iatron, Inc., Tokyo, Japan), an exclusive media in the same manner of normal phase TLC, using hexane:diethylether:formic acid (85:15:0.15, v/v) as development solvents, and quantified by IATRO SCAN (TH-10 TLC/FID analyzer, Iatron, Ltd., Tokyo, Japan) as previously described (An et al., 1997).

The instrumental color of fresh breast meat, including lightness $\left(\mathrm{L}^{*}\right)$, redness $\left(\mathrm{a}^{*}\right)$ and yellowness $\left(\mathrm{b}^{*}\right)$, were measured using a chromameter (CR 210, Minolta, Tokyo, Japan). The $\mathrm{pH}$ values of breast meats were estimated in 
Table 2. Dietary effects of onion extract on growth performance and carcass yield of White mini broilers ${ }^{1}$

\begin{tabular}{|c|c|c|c|c|c|c|}
\hline \multirow{2}{*}{ Items } & \multirow{2}{*}{ (-)Control } & \multirow{2}{*}{$(+)$ Control } & \multicolumn{2}{|c|}{ Onion extract } & \multirow{2}{*}{ SEM } & \multirow{2}{*}{ p-value } \\
\hline & & & $0.3 \%$ & $0.5 \%$ & & \\
\hline Initial BW (g/bird) & 39.1 & 39.1 & 39.1 & 39.0 & 0.03 & NS \\
\hline Final BW (g/bird) & $862.3^{\mathrm{b}}$ & $890.6^{\mathrm{a}}$ & $882.0^{\mathrm{ab}}$ & $880.3^{\mathrm{ab}}$ & 3.78 & 0.01 \\
\hline Feed intake (g/d/bird) & 49.8 & 49.6 & 50.4 & 49.5 & 0.51 & NS \\
\hline BW gain (g/d/bird) & $24.2^{\mathrm{b}}$ & $25.1^{\mathrm{a}}$ & $24.8^{\mathrm{ab}}$ & $24.7^{\mathrm{ab}}$ & 0.13 & 0.01 \\
\hline Gain:feed & 0.49 & 0.51 & 0.49 & 0.50 & 0.02 & NS \\
\hline Carcass yield (\%) & 66.2 & 67.32 & 66.3 & 66.3 & 0.47 & NS \\
\hline \multicolumn{7}{|l|}{$\%$ for carcass } \\
\hline Right breast muscle & 9.7 & 9.7 & 9.6 & 10.1 & 0.15 & NS \\
\hline Right leg & 7.6 & 8.1 & 7.6 & 7.7 & 0.15 & NS \\
\hline Right thigh & 8.0 & 8.2 & 8.4 & 7.9 & 0.16 & NS \\
\hline
\end{tabular}

SEM, standard error of the mean; BW, body weight; NS, not significant.

${ }^{1}$ (-)Control, basal diet; (+)Control, basal diet+10 ppm avilamycin.

${ }^{\mathrm{a}, \mathrm{b}}$ Means in the same row with no common superscript differ significantly $(\mathrm{p}<0.05)$.

triplicate with a $\mathrm{pH}$ meter (340 Mettler-Toledo, Greifensee, Switzerland). Briefly, $1 \mathrm{~g}$ of breast meat was cut into small pieces and homogenized with $9 \mathrm{~mL}$ of distilled water for 1 min in an Ultra-Turrax (Model No. T25, Janken and Kunkel, Staufen, Germany). To determine the cooking loss, $60 \mathrm{~g}$ of breast meat was boiled individually in polyethylene bags immersed in $80^{\circ} \mathrm{C}$ water bath for $30 \mathrm{~min}$ and cooled at room temperature for $30 \mathrm{~min}$. The cooking loss was calculated from the weights of uncooked and cooked meats. The shear force values were determined with a Warner-Bratzler shear attachment on a texture analyzer (Instron Corporation, Canton, MA, USA) with the following operating conditions; load cell $50 \mathrm{~kg}$ and cross-head speed, 180 $\mathrm{mm} / \mathrm{min}$. Each core sample was sheared once across the center of the core, perpendicular to the muscle fiber. The values were the mean of the maximum forces required to shear each set of core samples.

\section{Statistical analysis}

Each pen was considered as the experimental unit for performance parameter. The experimental unit was put on each bird for other measurements. All data were statistically analyzed using analysis of variance (SAS Institute, 2002), and significant differences of obtained means were determined using Duncan's multiple range tests at the level of $\mathrm{p}<0.05$ (Duncan, 1955).

\section{RESULTS AND DISCUSSION}

Growth performance and carcass characteristics of White mini broilers fed the experimental diets are presented Table 2 and 3. The final BW and daily BW gain in the groups fed a non-medicated control diet were significantly lower than those of medicated control group $(\mathrm{p}<0.01)$. The growth performance in chicks fed diet with $0.3 \%$ or $0.5 \%$ onion extract was slightly lower than that of medicated control group, but not significantly. There were no significant difference in feed intake and feed efficiency among groups.

The herbal products and spicy have been used in animal feed as digestion stimulants and growth promoters (Frankic et al., 2009). Jo et al. (2009) reported that the favorable influence of garlic extract on feed efficiency of broiler chickens. The broiler chickens fed diet with $3 \%$ onion bulbs had a greater BW gain (Goodarzi et al., 2014). Aji et al. (2011) also reported that the BW gain in chicks fed diets with garlic and onion was higher than control. It has been appeared that inclusion of onion into broiler diets did not have adverse effects on feed intake (Goodarzi et al., 2013). In present study, there was no significant effect on feed intake during starter and grower phases with slight increase in BW gain.

The carcass yield and the relative weights of edible parts were not affected by dietary treatments as shown in

Table 3. Dietary effects of onion extract on carcass characteristics of White mini broilers ${ }^{1}$

\begin{tabular}{|c|c|c|c|c|c|c|}
\hline \multirow{2}{*}{ Items } & \multirow{2}{*}{ (-)Control } & \multirow{2}{*}{ (+)Control } & \multicolumn{2}{|c|}{ Onion extract } & \multirow{2}{*}{ SEM } & \multirow{2}{*}{ p-value } \\
\hline & & & $0.3 \%$ & $0.5 \%$ & & \\
\hline Liver (g/100 g BW) & 2.24 & 2.32 & 2.08 & 2.19 & 0.06 & NS \\
\hline Spleen (g/100 g BW) & 0.12 & 0.16 & 0.15 & 0.12 & 0.01 & NS \\
\hline Bursa of Fabricius (g/100 g) & 0.29 & 0.32 & 0.29 & 0.33 & 0.02 & NS \\
\hline Abdominal fat $(\mathrm{g} / 100 \mathrm{~g})$ & 1.41 & 1.53 & 1.39 & 1.25 & 0.09 & NS \\
\hline
\end{tabular}

SEM, standard error of the mean; BW, body weight; NS, not significant.

${ }^{1}$ (-)Control, basal diet; (+)Control, basal diet+10 ppm avilamycin. 
Table 4. Dietary effects of onion extract on the enzyme activities and lipid fractions of serum and liver of White mini broilers ${ }^{1}$

\begin{tabular}{|c|c|c|c|c|c|c|}
\hline \multirow{2}{*}{ Items } & \multirow{2}{*}{ (-)Control } & \multirow{2}{*}{ (+)Control } & \multicolumn{2}{|c|}{ Onion extract } & \multirow{2}{*}{ SEM } & \multirow{2}{*}{ p-value } \\
\hline & & & $0.3 \%$ & $0.5 \%$ & & \\
\hline GOT (IU/L) & 121.62 & 114.64 & 118.14 & 118.18 & 3.47 & NS \\
\hline GPT (IU/L) & 5.42 & 5.74 & 5.92 & 5.98 & 0.49 & NS \\
\hline \multicolumn{7}{|l|}{ Serum lipid fractions } \\
\hline Cholesterol ester (mg/g) & 93.12 & 92.10 & 89.77 & 88.33 & 2.50 & NS \\
\hline Free cholesterol (mg/g) & $58.34^{\mathrm{a}}$ & $53.38^{\mathrm{ab}}$ & $49.54^{\mathrm{b}}$ & $48.74^{\mathrm{b}}$ & 1.67 & 0.01 \\
\hline Triacylglycerol (mg/g) & $403.32^{\mathrm{a}}$ & $347.68^{\mathrm{b}}$ & $319.04^{\mathrm{bc}}$ & $280.67^{\mathrm{c}}$ & 16.09 & 0.01 \\
\hline Phospholipid (mg/g) & 425.92 & 419.27 & 399.14 & 387.84 & 24.89 & NS \\
\hline \multicolumn{7}{|l|}{ Hepatic lipid fractions } \\
\hline Cholesterol ester (mg/g) & 4.41 & 4.32 & 4.21 & 4.21 & 0.10 & NS \\
\hline Free cholesterol (mg/g) & 1.96 & 1.97 & 1.95 & 1.94 & 0.06 & NS \\
\hline Triacylglycerol (mg/g) & 3.37 & 3.48 & 3.32 & 3.20 & 0.22 & NS \\
\hline Phospholipid (mg/g) & 15.63 & 14.20 & 15.22 & 15.02 & 0.49 & NS \\
\hline
\end{tabular}

SEM, standard error of the mean; GOT, glutamic-oxaloacetic transaminase; GPT, glutamic-pyruvic transaminase; NS, not significant.

${ }^{1}$ (-)Control, basal diet; (+)Control, basal diet +10 ppm avilamycin.

${ }^{\mathrm{a}-\mathrm{c}}$ Means in the same row with no common superscript differ significantly $(\mathrm{p}<0.05)$.

Table 2 and 3. These results are consistent with the result from Aji et al. (2011) who found no significant difference in the carcass yield obtained from broilers fed garlic and onion.

There were no significant differences in the activities of GOT and GPT in serum among groups (Table 4). After repeated doses of onion juice, the increased levels of serum aspartate aminotransferase and alanine aminotransferase could restore to normal levels in alloxan diabetic rats (ElDemerdash et al., 2005). They showed that onion juice exerted antioxidant effects and alleviated the tissue damage caused by alloxan-induced diabetes. In a previous study, we found that significant positive effect on antioxidant activity was shown with onion extract (Chang et al., 2010). The measurement of serum GOT and GPT activities indicative of tissue damage in bird is also a valuable tool to determine a safe inclusion level for non-conventional feedstuff and new additives (Lumeij, 1997; Diaz et al., 2003). The onion extract used in this study exhibited non pathologic and non toxic effects and safe as feed additives at an inclusion rate of $0.5 \%$ without having adverse effects on physiological responses.

The levels of serum cholesterol ester and phospholipid were not affected by dietary treatments. The concentrations of serum free cholesterol and triacylglycerol were significantly decreased in groups fed diets with onion extract relative to $(-)$ control $(\mathrm{p}<0.01)$. It is well known that dietary onion effectively lowers serum cholesterol levels in experimental rats as well as in humans. The decreased levels of blood cholesterol have been reported in rats fed normal diets with onion (Bakhsh and Chungtai, 1985) and high sucrose diet with onion essential oil (Adamu et al., 1982). Hypocholesterolemic effects with dietary onion may be attributed to decreased cholesterol secretion from liver, or to increased uptake of high density lipoprotein (HDL) uptake into liver. Goodarzi et al. (2013) observed that broilers fed diet with $3 \%$ onion had a significant higher HDL and lower blood triacylglycerol levels than those of control. There were no significant differences in the levels of various lipid fractions in liver among groups. Similar result has been reported by Sklan et al. (1992) who found no significant difference in hepatic cholesterol in chicks fed diet with onion. More research is needed to determine the effects of dietary onion extract on the synthesis, degradation and tissue distribution of cholesterol and triacylglycerol in meat-type chickens.

There were no significant differences of dietary onion

Table 5. Dietary effects of onion extract on physicochemical properties of breast muscles of White mini broilers ${ }^{1}$

\begin{tabular}{|c|c|c|c|c|c|c|}
\hline \multirow{2}{*}{ Items } & \multirow{2}{*}{ (-)Control } & \multirow{2}{*}{ (+)Control } & \multicolumn{2}{|c|}{ Onion extract } & \multirow{2}{*}{ SEM } & \multirow{2}{*}{ p-value } \\
\hline & & & $0.3 \%$ & $0.5 \%$ & & \\
\hline $\mathrm{pH}$ & 6.42 & 6.41 & 6.43 & 6.39 & 0.06 & NS \\
\hline \multicolumn{7}{|l|}{ Right breast muscle } \\
\hline $\mathrm{L}^{*}$ & 48.58 & 48.06 & 47.66 & 49.11 & 1.06 & NS \\
\hline$a^{*}$ & 2.44 & 2.37 & 2.46 & 2.43 & 0.31 & NS \\
\hline$b^{*}$ & 7.99 & 8.06 & 9.46 & 7.96 & 0.55 & NS \\
\hline Cooking loss (\%) & 22.30 & 21.44 & 20.04 & 21.19 & 1.00 & NS \\
\hline Shear force (kgf) & 2.63 & 2.54 & 2.89 & 2.94 & 0.22 & NS \\
\hline
\end{tabular}

SEM, standard error of the mean; NS, not significant; L*, lightness; $a^{*}$, redness; $b^{*}$, yellowness.

${ }^{1}$ (-)Control, basal diet; (+)Control, basal diet+10 ppm avilamycin. 
extract affecting $\mathrm{pH}$, color and cooking loss of breast meats in WMB (Table 5). The shear force values in chicks fed diets containing onion extract tend to be higher as compared with those of medicated or non-medicated controls, but not significantly. The texture of meat as well as the visual appearance are the main attributes that attract consumers to purchase quality poultry meats (Yang and Jiang, 2005). Jang et al. (2011) reported that dietary quercetin and methoxylated quercetin extracted from onion did not influence the $\mathrm{pH}$ and meat color in chicken thigh meats after slaughter. It is assumed that the dietary onion extract will not affect the physico-chemical properties and sensory characteristics of broiler meats, while there are scanty studies on the effect of onions on the meat quality.

In conclusion, these results suggested that onion extract may be able to use as substitute for in-feed antibiotics because the growth performance in chicks fed diet with onion extracts was comparable with medicated control. The onion extract could have beneficial effects in reducing the levels of blood free cholesterol and triacylglycerol of White mini broilers. Further research is needed to describe the effects of dietary onion extract on the metabolism and tissue distribution of cholesterol and triacylglycerol in meat-type chickens.

\section{ACKNOWLEDGEMENT} 2013.

This paper was supported by Konkuk University in

\section{REFERENCES}

Adamu, I., P. K. Joseph, and K. Y. Augusti. 1982. Hypocholesterolemic action of onion and garlic unsaturated oils in sucrose fed rats over two month period. Experientia 38:899-901.

Aji, S. B., K. Ignatius, A. Y. Ado, J. B. Nuhu, A. Abdulkarim, U. Aliyu, M. B. Gambo, M. A. Ibrahim, H. Abubakar, M. M. Bukar, H. M. Imam, and P. T. Numan. 2011. Effect of feeding onion (Allium cepa) and garlic (Allium sativum) on some performance characteristics of broiler chickens. Res. J. Poult. Sci. 4:22-27.

An, B. K., H. J. Im, and C. W. Kang. 2007. Nutritional values of red pepper seed oil meal and effects of its supplementation on performances and physiological responses of broiler chicks. Asian Australas. J. Anim. Sci. 20: 971-975.

An, B. K., H. Nishiyama, K. Tanaka, S. Ohtani T. Iwata, K. Tsutsumi, and M. Kasai. 1997. Dietary safflower phospholipid reduces liver lipids in laying hens. Poult. Sci. 76:689-695.

Bakhsh, R. and M. I. D. Chungtai. 1985. Comparative study of onion and garlic on serum cholesterol, liver cholesterol, prothrombin time and faecal sterol excretion in male albino rats. J. Chem. Soc. (Pakistan) 7:285-288.

Chang, W. K., S. B. Cho, D. W. Kim, S. S. Lee, and S. K. Kim. 2010. Cell growth and antioxidant activity on onion juice fermentation by using Lactobacillus plantarum as animal probiotics. J. Life Sci. 20:1729-1737.

Choo, Y. K., H. J. Kwon, S. T. Oh, J. S. Um, B. G. Kim, C. W. Kang, S. K. Lee, and B. K. An. 2014. Comparison of growth performance, carcass characteristics and meat quality of Korean local chickens and silky fowl. Asian Australas. J. Anim. Sci. 27:398-405.

Diaz, G. J., I. P. Roldan, and A. Cortez. 2003. Intoxication of Crotalaria pallida seeds to growing broiler chicks. Vet. Hum. Toxicol. 45:187-189.

Duncan, D. B. 1955. Multiple range and multiple $F$ test. Biometrics 11:1-42.

El-Demerdash, F. M., M. I. Yousef, and N. I. El-Naga. 2005. Biochemical study on the hypoglycemic effects of onion and garlic in alloxan-induced diabetic rats. Food Chem. Toxicol. 43:57-63.

Frankic, T., M. Voljc, J. Salobir, and V. Rezar. 2009. Use of herbs and spices and their extracts in animal nutrition. Acta Agric. Slovenica 94:95-102.

Goodarzi, M., M. Landy, and S. Nanekarani. 2013. Effect of onion (Allium cepa L.) as an antibiotic growth promoter substitution on performance, immune responses and serum biochemical parameters in broiler chicks. Health 5:1210-1215.

Goodarzi, M., S. Nanekarani, and N. Landy. 2014. Effect of dietary supplementation with onion (Allium cepa L.) on performance, carcass traits and intestinal microflora composition in broiler chickens. Asian Pac. J. Trop. Dis. 4 (Suppl. 1):S297-S301.

Jang, A., J. A. Ham, D. W. Kim, H. S. Chae, D. W. Kim, S. H. Kim, K. H. Seol, M. W. Oh, and D. H. Kim. 2011. Effect of quercetin and methoxylated quercetin on chicken thigh meat quality during cold storage. Korean J. Poult. Sci. 38:265-273.

Jo, J. K., S. Y. Yoon, J. S. Kim, Y. W. Kim, K. Yun, I. K. Kwon, and B. J. Chae. 2009. Effect of garlic extract supplementation on growth performance, nutrient digestibility, carcass characteristics and meat composition in broilers. Korean $\mathrm{J}$. Poult. Sci. 36:287-292.

Lumeij, J. T. 1997. Avian clinical biochemistry. In: Clinical Biochemistry of Domestic Animals (Eds. J. J. Kanebo, J. W. Harvey, and M. L. Bruss). 5th, Academic Press, CA, USA. pp. 857-883.

Melvin Joe, M., J. Jayochitra, and M. Vijayapriaya. 2009. Antimicrobial activity of some common spices against certain human pathogens. J. Med. Plants Res. 3:1134-1136.

SAS. 2002. SAS User's guide. Statistics, Version 8. e., SAS Institute Inc., Cary, NC, USA.

Sklan, D., Y. N. Bernera, and H. D. Rabinowitch. 1992. The effect of dietary onion and garlic on hepatic lipid concentrations and activity of antioxidative enzymes in chicks. J. Nutr. Biochem. 3:322-325.

Srinivasan, K., K. Sambaiah, and N. Chandrasekhara. 2004. Spices as beneficial hypolipidemic food adjuncts: A review. Food Rev. Int. 20:187-220.

Vidyavati, H. G., H., Manjunatha, J. Hemavathy, and K. Srinivasan. 2010. Hypolipidemic and antioxidant efficacy of dehydrated onion in experimental rats. J. Food Sci. Technol. 47:55-60.

Wenk, C. 2003. Herbs and botanicals as feed additives in monogastric animals. Asian Australas. J. Anim. Sci. 16:282289.

Yang, N. and R. S. Jiang. 2005. Recent advances in breeding for quality chickens. World's Poult. Sci. J. 61:373-381. 